\title{
Henry Evans Robson MB, BS, MRCS, LRCP
}

It was with great sadness that we heard of the death, on 11 February 1992, of Henry Evans Robson at the age of 69 . Henry was synonymous with BASM and there cannot have been a BASM member unfamiliar with Henry's name and huge personality.

Schooled in Sunderland, Edinburgh and Dorset, Henry graduated in medicine from Newcastle in 1946, proceeding to house jobs in Sunderland. There followed a busy Casualty Registrarship in Hartlepool and Durham, during which he set up the Hartlepool Casualty Department. He then changed to Anatomy; a Demonstratorship at Newcastle being followed by a Lectureship at Birmingham University.

His major career change then occurred following tuberculosis, in 1958, with his appointment as Principal Lecturer in Anatomy and Physiology at Loughborough Training College. His influence at Loughborough from then till 1970 was incomparable as the College evolved inexorably towards University status. Scores of PE students owed their grounding to Doc Robson, whose unique gift was somehow to inspire and needle the best out of them with his own enthusiasm, laconic humour and enormous goodheartedness.

Meanwhile, he had taken over from Denis Cussen the Treasurership of BASM in 1962, holding it safely until 1988. As if this wasn't enough, he started up the British Journal of Sports Medicine in 1962, initially as a small Bulletin shared with the Physical Education Association and growing steadily into an internationally indexed and appreciated Journal. Only Henry's ill-health forced him to step down, to become Chairman of the Editorial Board in 1986 and, finally, Editor Emeritus in 1989. Few appreciated the stupendous workload carried by Henry from 1962 until 1986. Each issue was edited and produced by him, from acknowledgement of manuscripts to running down to Wells and Blackwell at the last minute to fix up some tiny detail at the print and post stages. Fewer still appreciated that throughout all these achivements Henry suffered great medical distress with a stoicism defying description. An insulin dependent diabetic, whose epicurism survived intact, he then developed rheumatoid arthritis and finally a series of myocardial infarcts, none of which impaired his clear wit and judgment.

With changes occurring at the University, Henry changed his medical career once more, entering General Practice at Mountsorrel, near Loughborough, in 1970 at the age of 48 . Mainly because of Henry's position, it happened that many early BASM events were at Loughborough and that the first residential courses started there in 1975, of course with Henry as a co-organizer. Henry and Aida kept open house to BASM and the warmth of their hospitality will long be remembered by the many who usually made a point of not missing meetings at Kingfisher's Pool. Henry was always popular with overseas students, to whom he gave unstintedly of

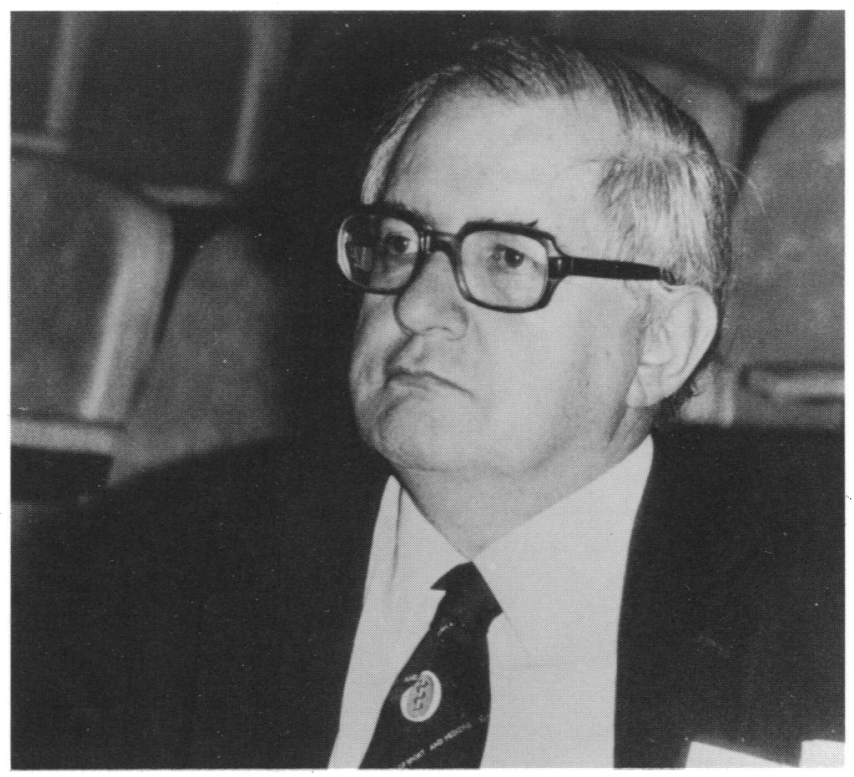

his teaching efforts. This led to lecturing visits to Mexico, Brazil, Australia, Thailand, Austria, Turkey, India, Holland, the Philippines, Sweden, Denmark and Malta.

For many years a Divisional Surgeon with the Leicestershire St. John's Ambulance Brigade, he also served as Medical Officer to the Special Olympic Games (for the handicapped) in Leicester in 1989 publishing his experience in this Journal - a commitment arising from his long service as $\mathrm{MO}$ to Glenfrith Hospital for mentally subnormal patients. He liked to garden, read, and listen to classical music and many patients benefited from his other hobby when he made his house calls on horse-back.

Henry is greatly missed for his wit and wisdom, his kindly compassion and his efficiency and vast experience, always so freely given to colleagues in need of guidance. Our deepest sympathy is extended to. Aida and Elizabeth.

Peter N. Sperryn

Henry Robson had a unique gift of being able to instil his own boundless enthusiasm for his subject into his students. During his time at Loughborough College he captured the imagination and lifelong interest of a large group of young students who have since gone on to great heights in the worlds of physiology, medicine and sport, and there can be no doubt that they owe their career interest to Henry's teaching of the basics of anatomy and physiology.

A recent head count demonstrated that at least two dozen university professors passed through his hands. He will be remembered not only as a gifted teacher but also as someone who encouraged others not only to follow but to go further and give of their time and knowledge unsparingly. It is said of great 
teachers that they inspire others and, if that is so, then Henry resides with these gifted few.

His summer school courses will always be remembered for their contribution to the knowledge of so many whose hopes and aspirations were assisted by their attendance. His deep interest in anatomy and his attempts to develop the companion volume to Sheldon's Atlas of Men will long be remembered by those who assisted him in their various ways.

Harry Thomason

As Editor of the British Journal of Sports Medicine Henry loved entertaining the Editorial Board with a sumptuous curry. There was always a good attendance! When Henry had his second heart attack he was still busy with BASM business, being Treasurer and Journal Editor and still continuing in general practice. Which did he want to do most? BASM business.

It was painful to have to pursuade him that the Association, though deeply grateful for all he had done, was in a vulnerable position if he should have further problems and with exceptionally good grace he relinquished the Journal to Peter Sperryn and the accounts to Harry Thomason. Despite this, Henry continued to take a close interest in all things BASM. He was the only member to write and comment on a BMJ letter from the Chairman in 1991 on GP tutor recognition of exercise physiology as a legitimate subject for GPs and it was a joy to see him at the Windermere AGM late in 1991.

Henry died painlessly, doing a crossword with his wife. He was cremated in his BASM tie and Disabled Games blazer - a fitting conclusion to a life devoted to Loughborough, Sports Medicine and his patients.

\section{Dan S. Tunstall Pedoe}

\section{Henry Evans Robson - an appreciation}

I first met Henry Robson at Loughborough in the summer of 1960 and was immediately taken by his enthusiasm, his interest and indeed his generosity. We soon became firm friends, as much because of, as in spite of, the difference in our professional backgrounds. Henry's career had been blighted by ill-health - diabetes and later tuberculosis interrupting his medical training and directing him away from clinical medicine at this time. $\mathrm{He}$ worked at the University of Birmingham and subsequently went to Loughborough College of Physical Education (as it then was) to teach Anatomy and Physiology. Generations of Loughborough students will attest to his success as a lecturer and indeed as a stimulator of interest in the scientific side of sport and sports training.

Henry and I worked together for many years side-by-side in the British Association of Sport and Medicine from the first provincial meeting at Loughborough in 1961 onwards, and in a whole variety of other activities in the field including the World Congress of Sports Medicine in Oxford of which he was Treasurer.

Henry was never a high-flyer but always an entirely dependable, willing and readily trusted
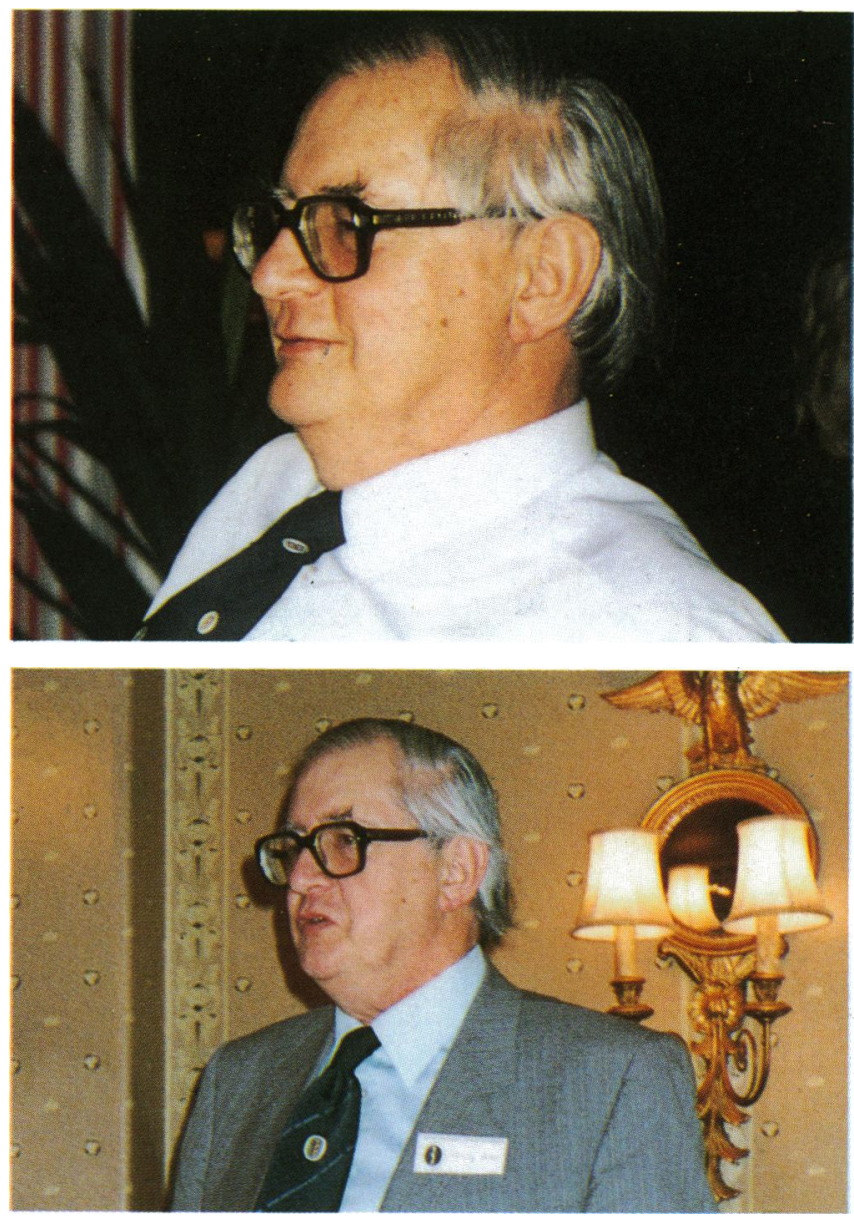

colleague. As Treasurer of BASM and as Editor of its Journal he put in immense hours of work and it was always his joy to keep the wheels rolling as smoothly as they did.

Socially he was a delightful companion and those who have shared the pleasure of having Henry as a colecturer on courses overseas will remember a delightful and not-to-be forgotten experience. At home he was a great family man as much with Aida, his wife, and Liz, his daughter, as with his 'family' of students and indeed his 'families' of the BASM and FIMS.

He never allowed himself to be caught up in the political machination that plagued the development of Sports Medicine in this country and indeed the FIMS in relatively recent times, always presenting the same outward face of calm to all the warring protagonists!

Later in life he was able to embrace a more clinical career leaving Loughborough to become a family doctor in practice in Mountsorrel. It was his sadness that further illness reduced his powers to engage in his beloved sports medicine in his later years.

It was a privilege to have known Henry, who was one of the few people of whom Marvell's epitaph on Charles I could truly be said ' $\mathrm{He}$ nothing common did nor mean'. Perhaps the best thing I have ever done for sports medicine in the UK was to recruit Henry Robson to BASM.

John G. P. Williams

Lately, Honorary Secretary, BASM and Secretary-General, FIMS 